\title{
Treća životna dob kao subjekt pastoralnoga djelovanja - mogućnosti i perspektive
}

\author{
STANISLAV ŠOTA* \\ • https://doi.org/10.31823/d.26.3.7 • UDK: 2-48-053.9 • Pregledni članak \\ Primljeno: 8. prosinca 2017. • Prihvaćeno: 17. rujna 2018.
}

Sažetak: Budući da je populacija u Europi i Hrvatskoj sve starija, a pastoralno djelovanje osoba treće životne dobi relativno nov pojam, rad prvotno analizira zašto su u pastoralnom diskursu osobe te dobne skupine i pastoralisti i pastoralaci u $\mathrm{Hr}$ vatskoj djelomično (o)stavili po strani. Narav i obilježja treće životne dobi koja iznosi prvi dio rada pokazuju kako pastoral treće životne dobi uključuje pastoralno djelovanje najzrelije srednje životne dobi prožeto mnogobrojnim životnim poteškoćama i stresovima: odvajanjem od djece, potrebom osobne iživotne prilagodbe, napose nakon odlaska u starosnu mirovinu,

${ }^{*}$ Doc. dr. sc. Stanislav Šota, Katolički bogoslovni fakultet u Đakovu Sveučilišta J. J. Strossmayera u Osijeku, P. Preradovića 17, 31400 Đakovo, Hrvatska, stanislav. sota@os.t-com.hr odlaska djece ili gubitka životnoga partnera te doživljavanjem brzih, progresivnih biološko-psihološko-mentalnih zdravstvenih dimenzija slabljenja organizma, životne energije, snage, sveopće oslabljenosti životnih i svih drugih funkcija. Starost je kao dar i mogućnost kroz nekoliko biblijskih likova prikazana kao evangelizacijska i pastoralna mogućnost, prilika i poziv na Bogom prožeti i osmišljeniji život. Drugi dio prikazuje treću životnu dob u svijetu i mentalitetu društva i Crkve. Promatrajući suvremeni životni kontekst, možemo ustvrditi kako su starost, umiranje i smrt postale strane riječi u svakodnevnom rječniku i to je jedan od mnogih razloga zbog kojih su osobe treće životne dobi često stavljene po strani, često ih ostave vlastite obitelji, društvo, prijatelji, rodbina, a djelomično ih zaboravi i Crkva. U svijetu diktature relativizma, materijalizma, sekularizacije, anarhizma, ateizma, subjektivizma, individualizma $i$ selfie-kulture, izrazito je teško i zahtjevno ostvarivati pastoral treće životne dobi. Crkva, posebice u Hrvata, nema dovoljno oblikovan, osmišljen, isplaniran i programiran sustavni pasto- 
ral u kojem bi bile zahvaćene osobe treće životne dobi. Novi bi se koncept pastoralnoga diskursa u pastoralu treće životne dobi trebao razvijati u dvama osnovnim pravcima: prvi je smjer promišljanja u kojoj mjeri treća životna dob može biti subjekt pastoralnoga djelovanja, a drugi, utemeljen na pastoralnoj sociologiji i demografskim kretanjima, nastoji prepoznati treću životnu dob kao objekt pastoralnoga djelovanja. Treća životna dob može biti uz objekt $i$ subjekt pastoralnoga djelovanja na različitim razinama, područjima i dimenzijama, posebice na župnoj, dekanatskoj u nekim vidovima, regionalnoj $i$ (nad)biskupijskoj razini i to na području apostolata, župnih pastoralnih vijeća, karitativnoga djelovanja, liturgije, obitelji, vjerskih udruga i pokreta te rada s distanciranim kršćanima.

Ključne riječi: treća životna dob, starost kao izazov pastoralnoj teologiji, treća životna dob kao subjekt $i$ objekt pastoralnoga djelovanja.

\section{Uvod}

Iako je populacija u Europi, a time i u Hrvatskoj, sve starija, pojam i područje pastoralnoga djelovanja osoba treće životne dobi ili pastoral starih osoba u pastoralnom


gija općenito, posebice u Hrvatskoj, pastoralno djelovanje, planiranje i programiranje sustavno promišlja o djetinjstvu, mladenaštvu i zreloj životnoj dobi stvarajući nove modele i načine što kvalitetnijega djelovanja, za razliku od pastorala vjernika treće dobi koji kao da su pastoralisti i pastoralci (ne)svjesno ostavili po strani. Nerijetko su pastoralni modeli tako postavljeni kao da pred sobom nemaju treću životnu dob, tj. vjernike sa životnim iskustvom, bogatstvom, znanjem, jasno postavljenim životnim ciljevima, traženjima i zahtjevima. Nadalje znakovito je da se u Crkvi od osoba treće životne dobi puno očekuje, podrazumijeva i pretpostavlja, osobito u prenošenju iskustva vjere, a vrlo malo se pastoralnim djelovanjem pruža, domišlja i pomaže. Uzroci takvoga stanja različiti su i mnogobrojni, a jedan od najčešćih jest društvena uvjetovanost. Naime krajem devetnaestoga stoljeća prosječni životni vijek bio je oko četrdeset godina, a u posljednjih je nekoliko desetljeća life-span u razvijenim zemljama dosegnuo sedamdeset i pet godina. ${ }^{2}$ Dakle, unatoč očitoj potrebi pastorala starih i starosti zbog produljenoga životnoga vijeka, pastoralni mentalni sklop ostao je uglavnom usredotočen na djecu, mlade i njihove roditelje. Pove-

\footnotetext{
${ }^{1}$ Usp. B. Z. ŠAGI, Pastoral starih osoba, u: Bogoslovska smotra 4(1983.)1, 246-255., ovdje 251.

${ }^{2}$ Takvo stanje rezultat je bolje i kvalitetnije zdravstvene zaštite, brige i mogućnosti te poboljšanoga standarda očitovanoga u boljim uvjetima stanovanja, kvalitetnijoj higijeni i prehrani; dakle, svjedoci smo i dionici općenito kvalitetnijih i boljih mogućnosti življenja nego naraštaji unazad nekoliko desetljeća. Usp. T. MALENICA, Psihologija treće životne dobi, Vid Pečjak, Prosvjeta, Zagreb, 2001., 248 str. (prikaz knjige) u: Revija za socijalnu politiku 9(2002.)3-4, 371-374., ovdje 371.
} 
ćana prosječna životna dob pastoralnoj teologiji kao praktičnoj teološkoj disciplini stoga mora biti i (p)ostati imperativ. U tom kontekstu današnja pastoralna teologija pozvana je očitovati svoj identitet u sveobuhvatnijem promišljanju i kvalitetnijoj brizi i skrbi u odnosu na osobe treće životne dobi. Starost kao sastavnica čovjekove egzistencije nije nesreća, ona je Božji dar koji omogućava dimenziju izgradnje i zaokruženosti vlastite osobnosti. ${ }^{3}$ Rad je strukturiran u tri dijela. Prvi dio govori o naravi i obilježjima treće životne dobi te biblijskom utemeljenju za pastoral starosti. Drugi dio stavlja naglasak na perspektive i mogućnosti pastoralnoga djelovanja, a treći donosi promišljanje o trećoj životnoj dobi kao subjektu (djelomično i objektu) pastoralnoga djelovanja.

\section{Narav i obilježja treće životne dobi}

\subsection{TreĆA ŽIVOTNA DOB I NJEZINE OSOBITOSTI}

Do prije gotovo stoljeća i pol na prostorima Hrvatske, osobito Slavonije, osoba treće životne dobi nije bilo mnogo, životni vijek bio je znatno kraći, život starijih osoba bio je egzistencijalna sastavnica svakodnevnoga života cijele obitelji. U današnjim okvirima dulje životnosti lako možemo zaključiti kako treća životna dob započinje početkom šestoga desetljeća životnoga vijeka. ${ }^{4}$ Sveti Efrem Sirski običavao je uspoređivati život s prstima jedne ruke kako bi istaknuo da svako životno razdoblje - baš kao i prst - ima svoje obilježje. Životna razdoblja opisuje kao pet stuba kojima se čovjekov život postupno uspinje $\mathrm{k}$ vrhuncu snage i životne energije, a nakon uspona životna snaga postupno jenjava, nestaje. ${ }^{5}$ Slovenski psiholog Vid Pečjak treću životnu dob dijeli na četiri vremenska razdoblja: od pedeset do šezdeset godina razdoblje je kasne srednje životne dobi, od šezdeset do sedamdeset godina mlađe starosti, od sedamdeset do osamdeset godina razdoblje srednje starosti, a nakon osamdesete godine života visoke starosti. ${ }^{6}$ Tako postavljena i definirana stvarnost starosti za pastoralnu je teologiju poseban izazov jer govor o pastoralu treće dobi uključuje pastoralno djelovanje najzrelije srednje životne dobi prožeto mnogobrojnim životnim poteškoćama i stresovima: odvajanjem od djece, sve težim praćenjem i snalaženjem na poslu, težim zapošljavanjem, a lakšim gubljenjem posla. ${ }^{7}$ Razdo-

\footnotetext{
${ }^{3}$ Usp. PAPINSKO VIJEĆE ZA LAIKE, Dostojanstvo i poslanje starijih u Crkvi $i$ u svijetu, Zagreb, 1999., 5.

${ }^{4}$ Usp. I. NEJAŠMIĆ, A. TOSKIĆ, Starenje stanovništva u Hrvatskoj - sadašnje stanje i perspektive, u: Hrvatski geografski glasnik 75(2013.)1, 89-110.

${ }^{5}$ IVAN PAVAO II., Salvifici doloris. Apostolsko pismo biskupima, svećenicima, redovničkim zajednicama i svim vjernicima katoličke Crkve o kršćanskom smislu ljudskog trpljenja, Zagreb, 1985., br. 12-16.

${ }^{6}$ Usp. T. MALENICA, Psihologija treće životne dobi (prikaz knjige V. Pečjaka), 372.

${ }^{7}$ Usp. S. H. McFADDEN, R. C. ATCHLEY, Aging and the meaning of time, New York, 2001., 51.
} 
blje mlađe starosti po svojoj naravi uključuje nužnost i potrebu osobne i životne prilagodbe, napose nakon odlaska u starosnu mirovinu, odlaska djece ili gubitka životnoga partnera. Zatim osobe u životnom razdoblju između sedamdeset i osamdeset godina prolaze kroz brze, progresivne biološko-psihološko-mentalne zdravstvene dimenzije slabljenja organizma, životne energije i snage, dok četvrto razdoblje - nakon osamdeset godina - karakterizira sveopća oslabljenost životnih i svih drugih funkcija. ${ }^{8}$ Moguće je, prema pojedinim autorima, osim navedene podjele i klasifikacije treće životne dobi, govoriti o životu i razdobljima životnoga vijeka kroz četiri životne dobi čovjeka. Naime, prema Clementsu, životni vijek od sedamdeset i pete godine života do stote godine života četvrto je životno doba čovjekova života. ${ }^{9}$ Cjelokupni je čovjekov život, prema umirovljenom pomoćnom biskupu Beča Krätzlu, poput živoga stabla: stablo prvotno raste - djetinjstvo i mladenaštvo, zatim donosi plodove - zrelo doba, nadalje imamo sliku stabla koje razgranatošću pruža drugima hladovinu - starost prožeta iskustvom i mudrošću te, napokon, suho lišće i ogoljenost stabla - slika koja ukazuje na činjenicu smrti. ${ }^{10}$ Papinsko vijeće za laike povodom Međunarodne godine starih osoba ističe: »Starost nije nesreća, nego Božji dar za dovršenje izgradnje vlastite osobnosti.« ${ }^{11}$ Osobe treće životne dobi nisu pozvane samo shvatiti kako je starost prilika za dublje shvaćanje i prepoznavanje Božjega nauma nego i kako je prilika koju treba iskoristiti kao »Božji dar za svoj duhovni rast, za puninu svoga sazrijevanja pred Bogom i za pomaganje mlađim naraštajima molitvom, savjetom, primjerom i iskustvom, osobito nenadomjestivim utjecajem na najmlađe članove obitelji ${ }^{12}$ Starost kao vrijeme spoznaje vlastitih granica na simboličkoj je razini snažna poruka crkvenom pastoralnom djelovanju iz koje pastoralni djelatnici moraju učiti od starosti relativizirajući uspjeh, postajući svjesni trenutne pastoralne važnosti, djela i rada, živeći i umirući za druge, odnosno ne dopuštajući da rezignirano-dezerterski evangelizacijski i pastoralno djelujemo, ${ }^{13}$ nego, suprotno, kroz logiku Isusa Krista - Dobroga Pastira - osobe treće starosne dobi doprinose kvalitetnijem pastoralnom djelovanju. ${ }^{14}$ Temeljna postavka pastorala naglašava kako se spasenjsko djelovanje po svojoj naravi odnosi na svako čo-

\footnotetext{
${ }^{8}$ Usp. V. PEČJAK, Psihologija treće životne dobi, Zagreb, 2001., 21.

${ }^{9}$ W. M. CLEMENTS, Issues in Pastoral Care and Counseling for the Fourth Quarter of Life, u: Pastoral psychology 49(2001.)6, 403-411., ovdje 407. U tekstu autor kada spominje treću životnu dob često misli i na navedeno Clementsovo četvrto životno doba.

${ }^{10}$ Usp. H. KRÄTZL, Darovano vrijeme. O umijeću starenja, Zagreb, 2010., 99-103.

${ }^{11}$ PAPINSKO VIJEĆE ZA LAIKE, Dostojanstvo i poslanje starijih u Crkvi i u svijetu, 5-6.

${ }^{12}$ Isto, 6.

${ }^{13}$ Usp. S. ŠOTA, Poimanje kerigmatske i mistagoške kateheze: osobne i pedagoške značajke te tipologija evangelizatora u Evangelii gaudium, u: Crkva u svijetu 51(2016.)1, 120-142., ovdje 137-138.

${ }^{14}$ Usp. isto, 139-140.
} 
vjekovo životno doba, a to znači da je potrebno spasenjski djelovati i za vjernike starosne dobi sve do njihove smrti. ${ }^{15}$ Starost je vrijeme životne rekapitulacije, ${ }^{16}$ životni vijek u kojem je dimenzija vremena na različitim razinama na cijeni, prilika za životne analize, osobni kritički osvrt na (ne)smisao života, ostvarivanje mladenačkih ideala, snova, želja i vrjednota. Danas demografi uz young old ${ }^{17}$ ističu i sve veću populaciju s više od sedamdeset i pet godina života tzv. oldest old. ${ }^{18}$ Sadašnje okolnosti upućuju na potrebu socijalne, ekonomske, kulturne, psihološke, a posebice duhovne prementalizacije u odnosu na starosnu dob, posebice potrebu prementalizacije unutar Crkve i društva u traženju novih oblika i načina pristupa starosti, brizi i skrbi. Crkva i društvo danas u starosti nužno trebaju prepoznavati konstruktivni doprinos i mogućnosti treće životne dobi u odnosu prema mlađim generacijama, napose njihovo snažnije i sveobuhvatnije vrjednovanje i omogućavanje angažmana starosne dobi na društvenoj i crkvenoj razini.

\subsection{Starost u Svetom pismu i njezino znaČenje ZA PASTORALNO DJELOVANJE}

U Svetom pismu pronalazimo na mnogim mjestima utemeljenje potrebe pastorala treće životne dobi kao subjekta i objekta pastoralnoga djelovanja. Tako primjer za starost kao vijek životnih analiza susrećemo u riječima: $\gg$ Spomeni se dana pradavnih, promotri godine od naraštaja ... « (Pnz 32, 7) Starost kao životni vijek doba je biološko-psihološko-egzistencijalne ovisnosti o mladosti i osobama životne zrelosti, napose njihova potomstva. Dimenziju poštovanja i uvažavanja mlađe generacije u odnosu na starost najzornije prepoznajemo u četvrtoj Božjoj zapovijedi: >Poštuj oca svoga i majku svoju, kako ti je Jahve, Bog tvoj, zapovjedio, da dugo živiš i dobro ti bude na zemlji koju ti Jahve, Bog tvoj, daje.« (Pnz 5, 16; usp. Izl 20, 12). Bog četvrtom zapovijedi na taj način antropološki utemeljuje potrebu brige za starije i upućuje na zajedništvo mladih i starih, zajedništvo u starosti i po starosti i prve, druge i treće životne dobi. U Starom i Novom zavjetu vrlo se lako može iščitati i uočiti snažno evangelizacijsko vrjednovanje, značaj i vrijednost starosti i osoba starosne dobi. Starosna dob u slučaju Abrahama i Sare (usp. Post 15, 1-6), Elizabete i Zaharije (usp. Lk 1, 5-20) očituje i ukazuje na snažnu evangelizacijsku snagu i potrebu osoba treće životne dobi da prenose, svjedoče i očituju iskustvo

\footnotetext{
${ }^{15}$ Usp. J. BALOBAN, Pastoralna teologija u Hrvatskoj, u: I. DŽINIĆ, I. RAGUŽ (ur.), Iščekivati i požurivati dolazak dana Božjega, zbornik radova, Đakovo, 2009., 15-32.

${ }^{16}$ Usp. American Psychological Association, Psychology and Aging, https://www.apa.org/pi/aging/ resources/guides/aging.pdf (9.11.2017.).

${ }^{17}$ Prema suvremenim demografima young old jesu osobe od šezdeset i pet do sedamdeset i pet godina života.

${ }^{18}$ Usp. PAPINSKO VIJEĆE ZA LAIKE, Dostojanstvo i poslanje starijih u Crkvi i u svijetu, 7.
} 
Boga, osobito potrebu cjeloživotnoga osluškivanja volje Božje. Nikodem je primjer kako su čovjeku i u starosti potrebni Bog i istina (usp. Iv 3, 1-21). On pokazuje kako osobe starosne dobi, unatoč velikom teološkom znanju i iskustvu, uvelike traže istinu, bit, vječno, neprolazno, Boga, spasitelja i otkupitelja. Osim toga on je očit primjer kako osobe treće životne dobi nerijetko proživljavaju velike osobne životne i vjerske krize. Starac Šimun (usp. Lk 2, 25-32) i udovica Ana s osamdeset i četiri godine životnoga vijeka (usp. Lk 2, 36-38) svjedoče kako starost unatoč nedaćama, poteškoćama, traženjima, napose strpljivom i ustrajnom čekanju i molitvi može biti vrijeme istinskoga mira, smiraja, egzistencijalnoga i teološkoga spokoja ako čovjek nastoji neprestano biti u Božjoj nazočnosti. Isus uz osobne susrete progovara o potrebi pomoći nemoćnima, starima, bolesnima, umirućima i žalujućima. Isusovo ozdravljenje sluge (usp. Mt 8, 5-17) na temelju satnikove vjere ukazuje na potrebu pastorala nemoćnih, bolesnih, onih koji pate i koji su ozbiljnoj egzistencijalnoj krizi. Ozdravljenje starice, Petrove punice (usp. Mk 1, 29-31), ukazuje na važnost i nužnost starosti kao objekta pastoralnoga djelovanja. Uskrišenjem Jairove kćeri (usp. Lk 8, 40-56), mladića iz Naina (Usp. Lk 7, 11-17) i prijatelja Lazara (Iv 11, 1-45) Isus Krist ukazuje na potrebu kvalitetnijega, sveobuhvatnijega i snažnijega pastorala i pastoralnoga djelovanja usmjerenoga prema bolesnima, umirućima i žalujućima. Pastoralno djelovanje treba biti tako postavljeno da spaja generacije, mlade i stare, nadvladava svako nepovjerenje, izolaciju i udaljavanje, ${ }^{19}$ uočava veliku osobnu kvalitativnu predodređenost za transcendenciju i Boga osoba treće životne dobi. No današnje pastoralno djelovanje ne samo da nerijetko odvaja, razdjeljuje i ne povezuje mladost, zrelost i starost pastoralnim planovima i programima nego i razdijeljenošću, napose slabom ponudom za starost, stvara prostor za bijeg od starosti. ${ }^{20}$ Dakle starost, bolest, starenje, prolaznost i patnja nisu jedini krivci razilaženja rođenja, smrti i vječnosti, ${ }^{21}$ nego su upravo posljedica nekvalitetnoga evangelizacijskoga pristupa, nedosljednosti i pretjerane pastoralne improvizacije. Ako želimo učiniti sintezu biblijskoga govora o starijim osobama, možemo im pripisati nazive mudraca, pomiritelja, osoba vjere, služenja, životne ostvarenosti i ispunjenosti, strpljivosti u boli i patnji, ustrajne molitve, cjeloživotnoga traženja i ostvarenosti u Bogu (usp. Tob 3, 1-6), napose svjedoka transcendencije (usp. 2 Mak 6, 28-38). Starije osobe sposobnije su u životu činiti potrebne kompromise kao sastavnice i nužnosti zajedničkoga života, a iskustvo i znanje koje posjeduju

${ }^{19}$ Usp. Papin nagovor uz molitvu Anđeo Gospodnji, nedjelja, 28. prosinca 2014. http://w2.vatican. $\mathrm{va} /$ content/francesco/hr/angelus/2014/documents/papa-francesco_angelus_20141228.html (3. 11.2017.).

${ }^{20}$ Usp. S. H. McFADDEN, R. C. ATCHLEY, Aging and the meaning of time, 229.

${ }^{21}$ Usp. J. S. LEVIN, L. M. CHATTERS, Religion, Health, and Psychological Well-Being in Older Adults, u: Journal of aging and health 10(1998.)4, 504-511. 
predstavljaju i mogu biti velik izvor dobra za sve generacije. ${ }^{22}$ Starije osobe mogu biti osvježenje svojoj obitelji i široj zajednici ako svojom vedrom nadom i dubokom vjerom idu prema kraju, ujedno i cilju vlastitoga života. ${ }^{23}$ Razdoblje mlađe starosti (između šezdeset i sedamdeset godina života) kroz životno stečenu mudrost može biti primjerom empatije, smirenosti, ljubaznosti i pružanja svjetla u noćima mnogim razočaranima, napose osobama besmisla. Mirnoća osmišljene treće životne dobi krije se u mudrosti, strpljivosti i blagosti te nerijetko u blagom humoru. Mirnoća znači moći čekati, prepustiti se vremenu, imati pouzdanja i povjerenja u Boga. Mirnoća je znak prihvaćanja starosti. ${ }^{24} \mathrm{~S}$ druge strane strah i tjeskoba u trećoj životnoj dobi velik su izazov za pastoral. Iz toga slijedi da sadašnje pastoralno djelovanje, planiranje i programiranje mora više računati na starost i više se na nju usmjeravati. Starost nije jednolična skupina niti se starost živi na isti način. Treća života dob ima onoliko lica koliko je u njoj osoba. ${ }^{25} \mathrm{Za} \mathrm{kvalitetnu} \mathrm{starost} \mathrm{osobe} \mathrm{tre-}$ će životne dobi najvažnije je shvatiti da je potrebno ostarjeti i starjeti u Bogu (usp. Izr 3, 1-18).

\section{Treća životna dob u svijetu i mentalitetu društva i Crkve}

Vikotor Frankl smatra da su trpljenje, bolest, smrt i patnja motivacijski preduvjeti za traženje smisla. ${ }^{26}$ Po njemu starost je poput egzistencijalnoga vakuuma. ${ }^{27} \mathrm{U}$ tom je kontekstu osjećaj ništavila svojstveni civilizacijski osjećaj u svijetu današnjega relativizma, kapitalizma i materijalizma, nerijetko prisutan u životima osoba treće životne dobi. Promatrajući suvremeni životni kontekst, možemo ustvrditi kako je starost u svakodnevnom rječniku postala strana riječ. Naime čovjek današnjice često potiskuje razgovor, promišljanje i susretanje s bolešću, odnosno prolaznošću i starošću. Znakovito je da značenje engleskoga izraza za smrt he is gone doslovno znači 'on je otišao. ${ }^{28}$ Danas je teško govoriti o bolesti, umiranju, starosti, a da se čovjek odmah ne sjeti i vlastite prolaznosti. Zbog toga osobe treće životne dobi često ostavi vlastita obitelj, društvo, prijatelji, rodbina, a djelomično zaboravi i Crkva.

${ }^{22}$ Usp. Forum special Active ageing, Promoting a European society for allages, European Commission of Employment and social affairs, http://aei.pitt.edu/82160/1/1999_Special_Issue_-_Active_Ageing.pdf (7. 11.2017.).

${ }^{23}$ Usp. B. Z. ŠAGI, Pastoral starih osoba, 250.

${ }^{24}$ Usp. J. ŽUPIĆ, Pastoral starijih i bolesnih u inozemstvu, u: Služba Božja 41(2001.)2, 143-149., ovdje 148.

${ }^{25}$ Usp. PAPINSKO VIJEĆE ZA LAIKE, Dostojanstvo i poslanje starijih u Crkvi i u svijetu, 13.

${ }^{26}$ Usp. V. E. FRANKL, Logotherapie und Existenzanalyse, München - Zürich, 1987., 142., citirano prema K. KATINIĆ, Živjeti za smrt, umrijeti za život, Zagreb, 2005., 21.

${ }^{27}$ Usp. isto, 21.

${ }^{28}$ A. YORES, Čovjek i njegova bolest, Zagreb, 1998., 58. 


\subsection{TREĆA ŽIVOTNA DOB U POIMANJU DANAŠNJEGA DRUŠTVA}

U svijetu beskrupuloznoga kapitalizma, ${ }^{29}$ diktature relativizma, cinizma današnje agresivne sekularizacije, ateizma, subjektivizma, individualizma i selfie-kulture izrazito je teško i zahtjevno ostvarivati pastoral treće životne dobi. Živimo u društvu u kojem starost, bolest, umiranje te smrt nisu poželjne dimenzije života u cjelini. ${ }^{30}$ Prema papi Franji, zbog današnjega mentaliteta kapitalizma i materijalizma, kojemu je važna samo čovjekova korisnost, proizvodnost, produktivnost, iskoristivost i zarada, starost je zaboravljena i (o)stavljena po strani jer jednostavno smeta i nije poželjna. ${ }^{31}$ Takav mentalitet često vodi podcjenjivanju treće životne dobi, zbog kojega osobe upadaju u krize. ${ }^{32}$ Starenje može biti i teško ako uz individualizam, personalizam i subjektivizam zavlada duh jednostranosti, životnih pogleda, interesa i očekivanja osoba prve, napose druge životne dobi. ${ }^{33} \mathrm{Na}$ društvenoj i osobnoj razini u svijetu i mentalitetu današnjega čovjeka nerijetko su osobe treće životne dobi (ne)svjesno ostavljene po strani, zaboravljene, poslane u domove namijenjene osobama starosne dobi (hospicij). Starije osobe zbog toga vrlo lako obolijevaju od psihičkih i fizičkih bolesti. Kultura društvenoga ravnodušja ${ }^{34}$ postupno, sustavno i potiho relativizira vrjednotu ljudskoga života, posebice starost, bolest, patnju i smrt, zbog čega je sve više starih osoba danas odvojeno od obitelji. Kultura ravnodušja osobito je prisutna u gradovima, gdje susjed do susjeda živi godinama nezainteresiran tko živi pored njega. Suvremeni čovjek kao da se danas želi anestezirati od svega što ga udaljava od uspjeha, mladosti i ljepote, a kao negaciju svega poželjnoga vidi upravo starost. ${ }^{35}$

\subsection{TREĆA ŽIVOTNA DOB U POIMANJU I PRISTUPU CRKVE I NJEZINOGA PASTORALNOGA DJELOVANJA}

Civilizacijski strah od smrti nije posljedica samo današnje kulture koja redovito ne želi prihvatiti stvarnost i činjenicu starosti i smrti nego i nekvalitetnoga pastoralnoga djelovanja Crkve. Nadvladavanje mentaliteta individualizma koji se kao me-

\footnotetext{
${ }^{29}$ Usp. M. VODOPIVEC, P. DOLENC, Živjeti dulje, raditi dulje: kako ostvariti taj cilj na tržištu rada?, u: Financijska teorija i praksa 32(2008.)1, 65-82.

${ }^{30}$ R. BUCKMAN, Ne znam što reći, Zagreb, 1996., 3.

${ }^{31}$ Usp. FRANJO, Evangelii gaudium, Zagreb, 2013. (= EG), br. 52-70.

${ }^{32}$ Usp. IVAN PAVAO II., Pismo pape Ivana Pavla II. starijim osobama, Zagreb, 2004., br. 9.

${ }_{33}$ Usp. H. KRÄTZL, Darovano vrijeme, 121.

${ }^{34}$ Usp. M. TOMEČAK, A. ŠTAMBUK, S. RUSAC, Promišljanje starenja i starosti - predrasude, mitovi i novi pogledi, u: Hrvatska revija za rehabilitaciju i istraživanja 50(2014.) 1, 39-53.

${ }^{35}$ Usp. PAPINSKO VIJEĆE ZA LAIKE, Dostojanstvo i poslanje starijih u Crkvi i u svijetu, 20-21.
} 
tastaza širi i na crkvene i pastoralne razine i dimenzije ${ }^{36}$ te se izravno suprotstavlja temeljima ljudskoga spasenja izazov je za pastoralno djelovanje. Trećoj životnoj dobi pitanje Boga i postojanja vječni je upitnik - za neke smislen, obogaćujući, iskustven, a za današnju populaciju nerijetko iritirajući. U tom smislu starost je vrijeme istinskih i življenih vrjednota, vrijeme profiliranja stavova. Osmišljena i kvalitetno življena treća života dob današnjem prešutnom ateizmu, sekularizmu, kroz dimenziju ljubavi, sebedarja i umiranja vrlo jasno ukazuje na Kristovo spasenje i otkupljenje, odnosno smisao života u onostranosti. Pastoralno djelovanje treće životne dobi mora čovjeka dovesti do prostora u kojem on shvaća da je život, a i time i starost, kao egzistencijalna i teološka nemoć preduvjet spoznaje moći u vlastitoj nemoći. ${ }^{37}$ Crkva u pastoralnom djelovanju treću životnu dob treba prepoznati kao evangelizacijski potencijal. Za sv. Ivana Pavla II. četvrta Božja zapovijed ne zauzima bezrazložno prvo mjesto na drugoj ploči Saveza. U središtu tih riječi jest istina da kršćanska zajednica može mnogo primiti od nenametljive, ali značajne i mnogobrojne nazočnosti vjernika poodmakloga životnoga vijeka u župnim zajednicama. ${ }^{38}$ Crkva općenito, posebice u Hrvata, nema dovoljno oblikovan, osmišljen, isplaniran i programiran sustavni pastoral kojim bi bile zahvaćene osobe treće životne dobi. U tom kontekstu pastoralna teologija prvotno si mora postaviti pitanje što Crkva može učiniti među vjernicima koji su sve stariji dio populacije. Prvi je korak pastoralno djelovanje prilagoditi novonastalim okolnostima, stvoriti nove pastoralne naglaske te osmisliti novu koncepciju pastoralnih modela i načela. ${ }^{39}$ Nova koncepcija pastoralnoga diskursa mora ići u dvama osnovnim pravcima. Prvi nužno treba ići u smjeru promišljanja u kojoj mjeri treća životna dob može biti subjekt pastoralnoga djelovanja, a drugi, utemeljen na analizi, pastoralnoj sociologiji i demografskim kretanjima, u smjeru prepoznavanja treće životne dobi kao objekta pastoralnoga djelovanja. Pastoralno djelovanje u Crkvi zahtijeva nove načine i modele, nužne su analize, pastoralna refleksija stanja i perspektiva pastoralnoga rada. $U$ pastoralu treće životne dobi potrebno se kritički osvrnuti na nositelje pastorala starih osoba. Prva je župna zajednica jer je kao zajednica ljudskih osoba povezanih vjerom u Krista mjesto gdje se zajedno slave euharistija i sakramenti. ${ }^{40}$ Ona je zajednica ustrojena na sliku obitelji, stoga po naravi već teži integraciji ljudskih osoba svih dobi, uzrasta i svakoga životnoga vijeka. Iz toga slijedi da župa mora u svojoj unutarnjoj

\footnotetext{
${ }^{36}$ Usp. J. BALOBAN, Djelovanje Crkve u novim društvenim okolnostima, Zagreb, 1995., 7-9.

${ }^{37}$ Usp. K. KATINIĆ, Živjeti za smrt, umrijeti za život?, 15-16.

${ }^{38}$ Usp. IVAN PAVAO II., Pismo pape Ivana Pavla II. starijim osobama, br. 11.

${ }^{39}$ Usp. J. ŠIMUNOVIĆ, Zašto odrasli imaju pastoralni prioritet u Crkvi danas?, u: Diacovensia 15(2007.)2, 37-54.

${ }^{40}$ Usp. N. VRANJEŠ, M. MIHAJIĆ, Izazovi i perspektive djelovanja vjernika laika u Hrvatskoj danas, u: Riječki teološki časopis 19(2011.)2, 437-460., ovdje 452-454.
} 
strukturi pronalaziti aktivni prostor za značajnije mjesto i ulogu starijih osoba kao subjekata pastoralnoga djelovanja u župnoj zajednici. ${ }^{41} \mathrm{U}$ brizi za stare osobe veliku važnost ima njihova obitelj koju je potrebno poticati na odgovornost prema starijim generacijama. Najmlađe članove obitelji potrebno je uključivati u odnose s osobama treće životne dobi jer se tako na poseban način afirmira vrijednost starosti. Svećenici, župnici, bolnički kapelani i duhovnici u staračkim domovima i zavodima dužni su vjernicima treće životne dobi u trenutcima nedostatka istinskoga pouzdanja, povjerenja i nade pružiti, omogućavati i osnaživati ostvarenje njihova traganja za vjerom, ufanjem i ljubavi prema Bogu i bratu čovjeku. ${ }^{42} \mathrm{U}$ vremenu kada suvremeni čovjek nema vremena ni za sebe, jer je zbog prezaposlenosti opterećen mnogim izazovima, svećenici i župnici pozvani su pronaći i imati uvijek vremena saslušati, osobno razgovarati s osobama treće životne dobi. Isto tako dužnost im je aktivno se uključiti u život župne zajednice kao subjekta pastoralnoga djelovanja u mnogobrojnim sadržajima na različitim područjima . ${ }^{43}$ Međutim današnji je kvalitetni pastoral starih osoba kao subjekta pastoralnoga djelovanja uvelike otežan zbog sveprisutnoga vjerskoga indiferentizma. Naime starost je zbog egzistencijalnoga i vjerskoga indiferentizma ${ }^{44}$ i sama nerijetko potopljena i utopljena u vjersko i egzistencijalno ravnodušje. Vjersko je ravnodušje evangelizacijski mlinski kamen u kojem se vjernici treće životne dobi osjećaju kao da su u močvari bezizlaznog ravnodušja te zbog toga u susretu s osnovnim životnim pitanjima i sami često bježe od sebe i pitanja Božje opstojnosti. Posljedica je takvoga stava sve prisutnija neautentičnost današnjih vjernika. ${ }^{45}$ Zato je na mnogim razinama i na mnogim pastoralnim $\mathrm{i}$ katehetskim područjima potrebna prementalizacija svih članova Crkve. U suprotnome ni starost kao doba naglašene čovjekove religioznosti ${ }^{46}$ ne će doživjeti radost Radosne vijesti.

\section{Perspektive i mogućnosti pastoralnoga djelovanja treće životne dobi}

Religioznost treće životne dobi karakterizira konkretnost, smisao, opipljivost, rad, djelovanje i vjerski oslonac. Kada se govori o starosti kao subjektu pastoralnoga djelovanja, uvelike se misli na sveobuhvatno pastoralno djelovanje treće životne dobi,

\footnotetext{
${ }^{41}$ HRVATSKA BISKUPSKA KONFERENCIJA, Na svetost pozvani. Pastoralne smjernice na početku trećega tisućljeća, Zagreb, 2002., br. 29.

${ }^{42}$ Usp. KONGREGACIJA ZA KLER, Prezbiter, pastir, vođa župne zajednice, Zagreb, 2003., br. 27-29.

${ }^{43}$ Usp. KONGREGACIJA ZA KLER, Svećenik - služitelj Božjeg milosrđa, Zagreb, 2014., br. 122-130.

${ }^{44}$ Usp. M. ŠKVORC, Jeruzalem ili Antiohija, Zagreb, 1989., 284.

${ }^{45}$ Usp. DRUGI VATIKANSKI KONCIL, Pastoralna konstitucija o Crkvi u suvremenom svijetu $\gg$ Gaudium et spes «, u: ISTI, Dokumenti, Zagreb, ${ }^{72008}$., br. 7.

${ }^{46}$ Usp. PAPINSKO VIJEĆE ZA LAIKE, Dostojanstvo i poslanje starijih u Crkvi i u svijetu, 28.
} 
njegovo značenje, napose sadržaj, mogućnosti i poziv osoba te dobi u navještaju, produbljivanju - katehiziranju i svjedočenju vjere mlađim generacijama. Kada se govori o trećoj životnoj dobi kao objektu pastoralnoga djelovanja, tada imamo pred sobom razvijanje, stvaranje, promišljanje o načinima kvalitetnijega pastoriziranja i evangeliziranja osoba treće životne dobi.

\subsection{TreĆA ŽIVOTNA DOB - SUbJEKT PASTORALNOGA DJELOVANJA}

$\mathrm{Na}$ više mjesta u crkvenim dokumentima i nagovorima susrećemo utemeljenje treće životne dobi kao subjekta pastoralnoga djelovanja. U dokumentu o pozivu i poslanju vjernika laika papa Ivan Pavao II. piše: » ...vi niste i ne smijete se osjećati na rubovima života Crkve, kao pasivni element u svijetu pretjerane pokretljivosti, nego kao aktivni subjekti ljudski i duhovno plodnog perioda ljudskog postojanja. Još imate poslanje koje treba ispuniti, doprinos koji imate dati. Po Božjem naumu svako ljudsko biće život je u rastu, od prve iskre do posljednjega daha. $\ll{ }^{47}$ Slika vala na moru vrlo zorno predočuje mogućnosti starenja: tko iskoristi treću životnu dob kao plodonosnu, plovi njome kao po valu; tko ju ne prihvaća, u njoj se gubi i nestaje. ${ }^{48}$ Spomenuta slika podsjeća kako osoba koja prihvaća svoju prolaznost i s njom živi, svoje životno iskustvo i stečenu mudrost, svoje znanje i vrjednote može svjedočkom dimenzijom prenijeti na mlađe generacije izazivajući u njima životni polet, osobito potičući mlađe generacije na napredak u vjeri i rast u prihvaćanju prolaznosti vlastitoga života. ${ }^{49}$ Starije osobe pomažu da sva zemaljska zbivanja primamo $\mathrm{s}$ više mudrosti jer su ih mijene kojima su oni prošle obdarile srećom i zrelošću. $U$ tom su kontekstu osobe treće životne dobi čuvarice zajedničkoga sjećanja i povlašteni tumači cjelokupnosti zajedničkih vrijednosti, vrjednota i ideala koji reguliraju društveni i vjerski život. Isključiti ih značilo bi, u ime nekoga moderniteta bez pamćenja, odbaciti prošlost u kojoj se ukorjenjuje sadašnjost. ${ }^{50}$ Vrijeme nakon umirovljenja za osobu je velika pastoralna mogućnost. ${ }^{51} \mathrm{U}$ tom kontekstu župna zajednica treba nuditi starijim osobama, umirovljenicima i bolesnicima sadržaje aktivnoga uključivanja u život župne zajednice (od aktivnoga uključivanja u župno pastoralno vijeće do svakoga i najmanjega angažmana u župnoj zajednici). Valja vrjednovati i koristiti se znanjem, iskustvom i mogućnostima starijih osoba u različitim područ-

\footnotetext{
${ }^{47}$ IVAN PAVAO II., Christifideles laici, Zagreb, 1990., br. 48.

${ }^{48}$ Usp. H. KRÄTZL, Darovano vrijeme, 6.

${ }^{49}$ Usp. M. BERČAN, The importance of inter generation a lintegration and communication on forming the view on quality aging, u: Media, culture and public relations 5(2014.)2, 231-240.

${ }^{50}$ Usp. IVAN PAVAO II., Salvifici doloris, br. 15.

${ }^{51} \mathrm{~S}$ druge strane mnogi doživljavaju negativno kao traumatski događaj uz različite osjećaje na emocionalnom, egzistencijalnom i društvenom vidu.
} 
jima župnoga pastorala. ${ }^{52}$ Odlazak u mirovinu i biološko starenje ne znače nužno beskorisnost starijih osoba. Potrebno je stoga omogućiti im uključivanje u život zajednice s onim sposobnostima i afinitetima kojima mogu dati najkvalitetniji doprinos. Dakle umirovljenje za osobe koje prihvaćaju vlastitu prolaznost i upućenost na Krista nije povlačenje iz aktivnoga života, nego novi životni korak koji je potreban i koji mnogi žele; koji treba biti oblikovan i koji je poželjno oblikovati. Redovitije i kvalitetnije prakticiranje vjere podloga je za bolju pastoralnu integraciju u župnu zajednicu. Takvim pristupom starije osobe mogu postati nositelji naviještanja i katehiziranja i biti suradnici u pripremanju i ostvarivanju mnogih područja pastoralnoga djelovanja. $U$ tom kontekstu najčešće će biti riječ o aktivnom sudjelovanju u životu pastoralnoga djelovanja na različitim razinama, područjima i dimenzijama, posebice na župnoj, dekanatskoj u nekim vidovima i regionalnoj i nadbiskupijskoj razini ${ }^{53}$. U tom kontekstu donosimo pregled mogućih razina, mjesta i dimenzija pastoralnoga djelovanja usmjerenoga prema osobama treće životne dobi:

a1) Obiteljska razina pastoralnoga djelovanja: Prema osobama treće životne dobi potrebno je odnositi se s osjećajem zahvalnosti, poštovanja i prihvaćanja kako bi se oni osjećali dijelom obiteljske zajednice i postali aktivni dionici pastoralnoga djelovanja prenoseći mlađim generacijama iskustvo žive vjere, vjersku pouku i svjedočanstvo o važnosti osobne molitve. Takvim angažmanom osoba treće životne dobi bit će istaknuta nužnost prakticiranja osobne vjere te povećana razina kvalitete kateheze djece koja je usmjerena na njihov stupnjeviti rast u vjeri. ${ }^{54} \mathrm{U}$ okolnostima u kojima mnogi bračni parovi, pa i cijele obitelji, zbog subjektivnih i objektivnih razloga ne uspijevaju ostvariti kvalitetnu obiteljsku povezanost ${ }^{55}$, a to se posebno odnosi na one $\mathrm{s}$ velikim poteškoćama, osobe treće životne dobi mogu svjedočiti i ukazivati na važnost komunikacije i prepoznavanja istinskih vrjednota u braku i obitelji. Naime starije su osobe >muškarci i žene, očevi i majke koji su bili prije nas na našem istom putu, u našemu istom domu, u našoj svakidašnjoj borbi za život dostojan čovjeka «. ${ }^{56}$ Upravo treća životna dob karizmom premošćivanja pomaže percipirati kontinuitet naraštaja, pa su tako često »djedovi i bake ti koji jamče prenošenje

\footnotetext{
${ }^{52}$ Usp. Ti si Krist za nas i za sve ljude. Izjave i odluke Druge biskupijske sinode đakovačke i srijemske, Đakovo, 2008., br. 87.

$53 \gg \ldots$ ona [evangelizacija] podrazumijeva i aktivno uključivanje starijih osoba i umirovljenika u različite oblike pastoralnog rada na župnoj i međužupnoj razini.« Usp. isto, br. 74.

${ }^{54}$ Usp. EG, br. 127-129.

${ }^{55}$ Usp. A. T. FILIPOVIĆ, Učiti živjeti zajedno, Zagreb, 1997., 29-34.

${ }^{56}$ Usp. FRANJO, Amoris laetitia, Zagreb, 2016., br. 191.
} 
velikih vrednota svojim unucima $\ll .{ }^{57}$ Prema tomu starost mlađoj generaciji ukazuje na nužnost kvalitetne komunikacije, razgovora, ljubavi, suživota, nesebičnosti, međusobne privrženosti, strpljivosti, bratstva, uzajamne brige, pružanja i primanja pomoći. Ukratko rečeno, upravo su starije osobe mlađima škola socijalizacije i nepresušan izvor kvalitetnoga savjetovanja i prenošenja iskustava bračnoga i obiteljskoga života. ${ }^{58}$

a2) župna razina pastoralnoga djelovanja. Treća životna dob volonterskim radom i osobnim angažmanom na župnoj razni može biti subjekt pastoralnoga djelovanja. »Starijim osobama, umirovljenicima i bolesnicima župna zajednica treba nuditi sadržaje uključivanja u župne aktivnosti (od aktivnog uključivanja u župno pastoralno vijeće, do svakog i najmanjeg angažmana u župnoj zajednici). Valjda vrednovati i koristiti znanje, iskustvo i mogućnosti starijih osoba u različitim područjima župnog pastorala. ${ }^{59}$

- na području apostolata: katehizirati i angažirati se u jednom od živih vjerničkih krugova ${ }^{60} \mathrm{u}$ župi, katehizirati jednu od skupina djece, posebice odraslih; promicati župno misijsko djelovanje, biti nositelj rada s osobama s invaliditetom, biti promicatelj biblijskoga pastorala, nositelj i promicatelj pastorala branitelja i stradalnika Domovinskoga rata, promicati i razvijati mrežu molitelja za duhovna zvanja, sudjelovati i promicati medijski pastoral, biti župni dopisnik, izrađivati župnu mrežnu stranicu, brinuti se i stvarati medijski arhiv. U župnim obiteljskim skupinama prenositi bitne sastavnice, odrednice i vrjednote bračnoga i obiteljskoga života mladim bračnim parovima; osobnim angažmanom biti uključen u župnu obiteljsku skupinu bračnih parova i zajedno s njima produbljivati, razmjenjujući iskustva i razgovarajući, osobnu dimenziju vjere, rasta u vjeri, važnosti kvalitetne bračne i obiteljske komunikacije i duhovnosti. Osobe treće životne dobi apostolat mogu ostvarivati osobnim angažmanom u vjerskom turizmu, ${ }^{61}$ sadržajima kao što su hodočašća, putovanja i duhovne vježbe. Jedan od vidova angažmana osoba starije dobi u župnim zajednicama može biti organizacija stručnih, molitvenih i drugih skupova. Pritom je prikladno da organizator svojim zanimanjem bude blizak ili stručan u razlaganju određene teme. Osim spomenutih aktivnosti, aktivni vjernici starije dobi u kontekstu naviještanja mogu se angažirati u odnosu na distancirane ili nepoučene vjer-

\footnotetext{
${ }^{57}$ Usp. isto, br. 192.

${ }^{58}$ Usp. isto, br. 194-195.

${ }^{59}$ Ti si Krist za nas i za sve ljude, br. 87.

${ }^{60}$ Više o živim vjerničkim krugovima vidi M. ŠIMUNOVIĆ, Župna kateheza - kateheza zajednice. Nužnost pastoralno-katehetskih zaokreta, u: Diacovensia 24(2009.)2, 257-277.

${ }^{61}$ Turistički angažman podrazumijeva razne projekte i njihovu organizaciju.
} 
nike kojima osobnim iskustvom i svjedočanstvom vjere mogu progovoriti na razumljiviji i prihvatljiviji način, rušeći tako barijere koje su spomenute vjernike udaljile od Crkve. Taj se vid naviještanja ostvaruje u osobnim susretima sa spomenutim vjernicima, u pastoralnim pohodima njihovim domovima i obiteljima, kako bi se što više naglasila želja za dijeljenjem znanja i iskustva vjere s njima, koje će rezultirati i njihovim aktivnijim vjerničkim životom. $\mathrm{Na}$ području župnoga pastoralnoga vijeća ${ }^{62}$ osobe treće životne dobi takav vid svojega angažmana mogu ostvariti kao aktivni članovi župnoga pastoralnoga ili ekonomskoga vijeća. Uz angažman u župnom pastoralnom vijeću mogu biti i članovi odbora ${ }^{63}$ za naviještanje ${ }^{64}$ koji je jedan od triju odbora koji postoje u okviru župnoga pastoralnoga vijeća ili pridruženi član ${ }^{65}$ odbora za naviještanje župnoga pastoralnoga vijeća.

- na području karitativnoga djelovanja: promicati karitativno djelovanje, posebice kroz župni karitas ili u okviru župnoga pastoralnoga vijeća animirati te osobno se angažirati u odbor za karitativnu djelatnost ${ }^{66}$ koji djeluje u okviru župnoga pastoralnoga vijeća ili biti njegov pridruženi član. ${ }^{67}$ Osim toga, u skladu sa svojim sposobnostima i mogućnostima, osobe starije životne dobi mogu u župi organizirati sustavnu brigu i posjete nemoćnima, starima, osamljenima, napuštenima, bolesnima; brinuti se za samce; osobno biti angažirani i u posjetima staračkim domovima na području župe. U trenutcima starosti, kada se osobe nerijetko osjećaju beskorisno, kršćanska diakonija po domišljatoj ljuba-

${ }^{62}$ Usp. Ti si Krist za nas i za sve ljude, br. 573.

${ }^{63} \gg$ Župno pastoralno vijeće u načelu ima tri odbora: za naviještanje, za liturgiju i za služenje. Pastoralno vijeće će, na čelu sa župnikom, vrednujući sastav, potrebe i pastoralne prioritete župe, kad se ukaže potreba, osim četiri navedena odbora, osnovati i druge odbore. Članovi vijeća imaju obavezu biti u jednom od odbora, sudjelovati u njegovu radu te pridonositi i radu ostalih odbora unutar župnog vijeća.«Isto, br. 575.

${ }^{64}$ S. ŠOTA, Analiza i kritički osvrt na župna pastoralna vijeća i njihove odbore u Đakovačko-osječkoj nadbiskupiji, u: Obnovljeni život 71(2016.)1, 85-101., ovdje 88., 99-100.

${ }^{65}$ Člana ŽPV-a potvrđuje biskup nakon izbora, a pridruženoga člana nekoga odbora ŽPV-a imenuje župnik. Jedna osoba može istovremeno biti član ŽPV-a i jednoga od odbora ŽPV-a. Usp. Pravilnik župnog pastoralnog vijeća u Đakovačko-osječkoj nadbiskupiji, Nadbiskupski arhiv Đakovačko osječke nadbiskupije, br. 420/2011. od 20. 1.2011., 4.

${ }^{66}$ Odbor za karitativnu djelatnost posvećuje brigu siromašnima, socijalno ugroženima te osobama na rubu društva. Razmatra socijalne i druge probleme svoje okoline te nastoji u granicama mogućnosti župe pružiti djelotvornu pomoć. Promiče suradnju s vjerničkim društvima i socijalnim ustanovama, organizira pastoral starijih osoba i bolesnika te članova njihovih obitelji. Usp. isto.

${ }^{67}$ S. ŠOTA, Analiza i kritički osvrt na župna pastoralna vijeća i njihove odbore u Đakovačko-osječkoj nadbiskupiji, 90-91., 99-100. 
$\mathrm{vi}^{68}$ nastoji pronaći načine pomoći i biti potpora onima kojima je potrebna materijalna i duhova pomoć, usamljenima i nezbrinutima. Karitativna djelatnost stoga ne smije biti svedena samo na materijalnu pomoć, nego još više na ukazivanje pomoći darivanjem svojega vremena i svojih vještina, u čemu su osobe treće životne dobi neiscrpni izvori. Tako mogu mlađim članovima župnih zajednica pomoći znanjem (instrukcijama učenicima iz pojedinih školskih predmeta) ili poučavanjem nezaposlenih osoba određenim vještinama (poukom izrade predmeta od drveta) ${ }^{69}$

- na području liturgije: animirati i osobno sudjelovati u župnim liturgijskim skupinama, crkvenim zborovima, animiranju pjevanja u crkvi, animirati jednu od molitvenih skupina, biti osobno uključen u službu čitača ${ }^{70}$, biti izvanredni djelitelj pričesti ili obavljati neku drugu službu koja pripada odboru za liturgiju župnoga pastoralnoga vijeća ili se angažirati kao pridruženi član spomenutoga odbora. ${ }^{71}$

- na području vjerničkih udruga i pokreta: Vjernički pokreti osnivaju se zbog posebnih potreba ili specifičnih karizmi koje mogu biti življene i ostvarene unutar župne zajednice, a za što je potrebna strukturiranost i uređenost udruge. Različiti su motivi i karizme koji prethode osnivanju vjerničkih pokreta, a njihova raznolikost ostavlja prostor za uključivanje i osobama treće životne dobi kako bi svojim sposobnostima, potrebama i specifičnim darovima vodili i izgrađivali pojedinu vjerničku udrugu. Snaga je tih udruga u snažnom promicanju evangelizacijskoga poslanja vjernika laika i uključivanju njihovih članova, među kojima može biti i velik broj osoba treće životne dobi, u pastoralne strukture dijaloga i suodgovornosti u župi i biskupiji, posebice na onim područjima koja su im svojstvena i bliska, a odgovaraju raznovrsnim pastoralnim potrebama. $^{72}$

${ }^{68} \mathrm{U}$ okviru župne zajednice osobe treće životne dobi mogu primljene i afirmirane darove besplatno kroz dimenziju korisnosti i služenja Kristu pružati potrebnima kroz vid primjerice konzultacija profesora u mirovini siromašnim studentima, poduke sviranja nekoga instrumenta, instrukcija itd.

${ }^{69}$ Usp. J. ŠIMUNOVIĆ, Djelovanje župne zajednice ad extra, u: Bogoslovska smotra 77(2007.)1, 245262., ovdje 258.

${ }^{70}$ S. ŠOTA, Analiza i kritički osvrt na župna pastoralna vijeća i njihove odbore u Đakovačko-osječkoj nadbiskupiji, 90., 99-100.

${ }^{71}$ Ako u župi u redovitim ili pojedinim prilikama postoji potreba, a odlikuju se prikladnim vjerničkim životom, osobe starije životne dobi mogu obavljati službu izvanrednih djelitelja pričesti. Izvanredni djelitelji pričesti svojim vršnjacima donose posebnu dimenziju razumijevanja i suosjećanja jer su i sami na zalazu svojega života i bolje od svih drugih razumiju njihove teškoće. Usp. Ti si Krist za nas i za sve ljude, br. 359, 365.

${ }^{72}$ Isto, br. 176-180. 
a3) dekanatska, gradska, regionalna razina pastoralnoga djelovanja osoba treće životne dobi. Osobe treće životne dobi mogu biti subjekt pastoralnoga djelovanja u savjetovalištima: na razini grada, u tečajevima za zaručnike, u promicanju pastorala bolesnika, zatvorenika, beskućnika, u promicanju ekumenskoga dijaloga, pastoralu intelektualaca ili ovisnika (npr. rad u klubu za AA). Po svojoj naravi neke od spomenutih aktivnosti u koje su uključene starije osobe mnogu se ostvariti i na višim razinama koje su ovdje spomenute, primjerice angažman u vjerničkim udrugama, karitativno djelovanje u organizacijama viših razina, živi vjernički krugovi i aktivnosti na području pastorala braka i obitelji.

a4) na nadbiskupijskoj razini osobe treće životne dobi mogu biti subjekt u mnogim već spomenutim pastoralnim područjima, posebice angažmanom u nadbiskupijskim povjerenstvima i vijećima za brak i obitelj, za rad s osobama s invaliditetom i slično. Treća životna dob može i na toj razini biti subjekt pastoralnoga djelovanja u biskupijskim katehetskim i pastoralnim vijećima. Budući da biskupijska pastoralna vijeća izražavaju zajedništvo i jedinstvo svih vjernika u različitosti karizmi i službi, tako i osobe treće životne dobi mogu sudjelovati u njihovu radu. Aktivnost starijih očituje se u promicanju sustavnoga evangelizacijskoga poslanja vlastite biskupije, kritičkoga vrjednovanja i prosuđivanja pastoralno-evangelizacijskoga djelovanja i predlaganju smjernica za rad pastoralnih povjerenstava unutar biskupijskoga pastoralnoga centra. ${ }^{73} \mathrm{Osim} \mathrm{u}$ pastoralnom vijeću, osobe treće životne dobi mogu sudjelovati u radu katehetskoga biskupijskoga vijeća koje obično čine katehete i vjeroučitelji. Osim katehetskih i vjeroučiteljskih zadaća, kao članovi toga vijeća, starije osobe bave se radom u povjerenstvima za župnu katehezu. ${ }^{74}$ Dakle starost može biti poticaj za dijeljenje posljednjega razdoblja života s drugima, posebice poziv na svjedočenje vjere na svim razinama, u svakom trenutku, svakoj osobi, osobito mladima. $^{75}$

\subsection{Treća Životna dob - ObJekT PAStoralnoga DJELOVANJA}

Starenje je umijeće koje se mora naučiti, kao što se uči senzibiliziranju crkvene i društvene stvarnosti za dostojanstveno ophođenje sa starim osobama. ${ }^{76} \mathrm{U}$ trećoj životnoj dobi naglašena postaje svijest partikularizma znanstvenih disciplina koje

\footnotetext{
${ }^{73}$ Usp. Statut Pastoralnog vijeća Đakovačko-osječke nadbiskupije, Nadbiskupijski arhiv Đakovo, br. 1290/2014., od 29. 8. 2014., 4.

${ }^{74}$ Ti si Krist za nas i za sve ljude, br. 135.

${ }^{75}$ Usp. A. MATELJAN, Svećenik i bolesnik. Načela za kršćansku komunikaciju svećenika i bolesnika u bolnici, u: Služba Božja 48(2008.)4, 380-407., ovdje 391.

${ }^{76}$ Usp. H. KRÄTZL, Darovano vrijeme, 20.
} 
su čovjeku pružale snagu i motiv za suočavanje s najtežim trenutcima: medicina, psihologija, psihoterapija i filozofija. Ta je životna dob najzahvalnija za pastoralno djelovanje jer je, osim prostora propitivanja dosadašnjega vida vjere, prostor $\mathrm{i}$ vrijeme njezina izrazitoga produbljenja. Crkva mora dovesti osobu do samovrjednovanja i zdrave samokritičnosti, pa je za osobe treće životne dobi važno otvoriti se sadašnjem trenutku života i prepoznati ključne trenutke vlastite starosti. ${ }^{77} \mathrm{Cr}$ kva u pastoralnom djelovanju ne smije dopustiti dimenziju umora na razini smisla, produbljenja, prenošenja, oduševljenja i važnosti vjere. U tom smislu potrebno je vjernike odgajati za prihvaćanje starosti, bolesti, patnje i smrti promičući kršćanski pristup tim stvarnostima. Istovremeno je važno sve odgajati za poštovanje dostojanstva osoba te dobi te za istinsku međugeneracijsku solidarnost koja uključuje vrjednovanje i prihvaćanje svega blaga koje oni u sebi nose. ${ }^{78}$ Važno je stoga prisjetiti se da nam život starijih osoba osvjetljava ljestvicu ljudskih vrjednota i pokazuje neprekidnost naraštaja te je čudesan dokaz međuovisnosti Božjega naroda. Starije osobe često imaju karizmu prevladavanja prepreka među naraštajima prije nego one postanu nesavladive. ${ }^{79}$ Aktualna pastoralna praksa treće životne dobi ${ }^{80}$ kao objekta pastoralnoga djelovanja najsnažnije se treba usmjeriti na pastoral u domovima za stare, župnim zajednicama i obiteljima, kroz dimenziju prikladnoga ophođenja, prihvaćanja te bliskosti prožete susretom i slušanjem, ali i osmišljavanjem prigodnih i redovitih sadržaja vjerskoga, kulturnoga i društvenoga karaktera. Pastoral treba koordinirati odbor za evangelizaciju starijih osoba i bolesnika koji djeluje u okviru odbora za karitativno djelovanje župnoga pastoralnoga vijeća. Iste aktivnosti na višoj razini treba koordinirati nadbiskupijski odbor za pastoral starijih osoba i bolesnika djelujući u okviru nadbiskupijskog pastoralnog centra. ${ }^{81}$ Materijalizam, kapitalizam i selfie-kultura uvelike utječu na civilizacijski $i$ kulturni odmak i bijeg od bolesti, bolesnika, a posebno sakramenta bolesničkoga pomazanja. Prema Direktoriju za pastoral sakramenata u župnoj zajednici, pastoral bolesničkoga pomazanja zahtijeva opću razinu koja podrazumijeva potrebu promjene poimanja biti bolesti, a onda i sakramenta bolesničkoga pomazanja. Druga razina pastoralnoga djelovanja jest ona župna, prigodnoga karaktera, a uključuje prigodne susrete, programe, prigod-

\footnotetext{
${ }^{77}$ Usp. A. MATELJAN, Svećenik i bolesnik, 389.

${ }^{78}$ Usp. Ti si Krist za nas i za sve ljude, br. 75.

${ }^{79}$ HRVATSKA BISKUPSKA KONFERENCIJA, Direktorij za obiteljski pastoral Crkve u Hrvatskoj, Zagreb, 2002., br. 54.

${ }^{80}$ Drugi dio trećega poglavlja koji govori o pastoralu treće životne dobi kao objektu pastoralnoga djelovanja zbog objektivnih okolnosti - širine, značenja, sadržaja, mnogobrojnosti područja, posebice mogućnosti napisati i provesti cijele studije i istraživanja - navest će samo najvažnije pastoralne naglaske.

${ }^{81}$ Usp. Ti si Krist za nas i za sve ljude, br. 76.
} 
na euharistijska slavlja s bolesnicima i pohod svećenika ili izvanrednoga djelitelja svete pričesti bolesniku. Treća - obiteljsko-osobna razina - očituje se u osobnoj angažiranosti prema osobama starije dobi kojima je potrebna pastoralna briga i skrb. ${ }^{82}$ Drugi preporučeni oblici bolesničkoga pastorala, poput duhovnoga razgovora i nazočnosti svećenika u procesu liječenja, u većini bolnica ostvaruju se samo djelomično zbog spomenutoga mentaliteta i kulture. Uključivanjem kvalificiranih vjernika laika u bolnički pastoral pastoralna bi se praksa zasigurno kvalitativno poboljšala. ${ }^{83}$ Budući da je Crkva pozvana pratiti čovjeka od rođenja sve do smrti, ${ }^{84} \mathrm{u}$ pastoralu bolesničkoga pomazanja potrebno se voditi pastoralnom razboritošću te uključiti i članove obitelji osoba koje pristupaju tom sakramentu. ${ }^{85}$ Umiranje je danas posebno teško jer je nerijetko osamljeno, mehanizirano i neosobno, izvan obitelji. Zato pastoral umirućih mora osigurati umirućima dostojanstvenu smrt te cjelokupnu crkvenu i društvenu stvarnost posredstvom medija, obrazovnoga sustava i drugih institucija senzibilizirati za njihovo dostojanstvo. Danas Crkva pastoral umirućih najčešće ostvaruje palijativnom skrbi i hospicijima, što ukazuje na potrebu podržavanja i osnivanja hospicija te ustanova za prihvat nemoćnih osoba. Palijativna skrb pastoralna je prilika zbog posvećenosti sveobuhvatnoj brizi za teško bolesne osobe sve do njihove smrti. ${ }^{86} \mathrm{U}$ tom procesu važno je bolesniku spoznati smisao patnje i teškoća koje mu se događaju. ${ }^{87}$ Poželjan je angažman širega kruga ljudi koji obuhvaća obitelj umirućih, svećenika dušobrižnika, medicinsko osoblje, socijalnoga radnika, laike uključene u pastoral te cijelu župnu zajednicu. ${ }^{88} \mathrm{U}$ okolnostima sve veće udaljenosti čovjeka od Boga i crkvene prakse smrt člana obitelji postaje pastoralnom prigodom za izravan susret župnika sa župljanima. Proces žalovanja je sa svojim fazama pastoralna mogućnost jer se nakon smrti člana obitelj suočava $s$ razdobljem prilagodbe koja nastupa zbog narušenosti dotad postojeće percepcije života. Psiholog John Bowlby žalovanje promatra u četirima fazama: prva je otupjelost (mrtvilo i zaprepaštenje), druga je čežnja i potraga za izgubljenom osobom,

\footnotetext{
${ }^{82}$ Usp. HRVATSKA BISKUPSKA KONFERENCIJA, Direktorij za pastoral sakramenta u župnoj zajednici, Zagreb, 2008., br. 160-178.

${ }^{83}$ Usp. A. MATELJAN, Svećenik i bolesnik, 384.

${ }^{84}$ Ž. BEZIĆ, Pastoralni rad, Zagreb, 1993., 284.

${ }^{85}$ Usp. A. MATELJAN, Svećenik i bolesnik, 386.

${ }^{86}$ Usp. G. BEUKEN, Palliative Care: A Theological Foundation Sacrament of Anointing \& Pastoral Care of the Sick, u: Scottish Journal of Healthcare Chaplaincy 5(2002.)1, 36-40.

${ }^{87}$ Usp. M. BABIĆ, Uloga duhovnosti u palijativnoj skrbi, u: Služba Božja 53(2013.)3-4, 435-440., ovdje 438-440.

${ }^{88}$ Usp. HRVATSKA BISKUPSKA KONFERENCIJA, Direktorij za pastoral sakramenta u župnoj zajednici, br. 160-178.
} 
treća je dezorganizacija, očaj i gubitak nade u povratak i naposljetku reintegracija. ${ }^{89}$ Ožalošćeni moraju proći sve faze žalovanja koje nisu strogo odijeljene, nego se preklapaju sve dok žalovanje nije razriješeno i završeno. ${ }^{90}$ Pastoral žalujućih moguće je oblikovati u smjeru ostvarivanja prigode za ljudski susret i evangelizaciju, osobito u teškim slučajevima poput smrti mlade osobe, smrti hranitelja obitelji ili tragične smrti. Kao primanje pri pripravi sprovoda hvale je vrijedan i posjet obitelji nakon sprovoda. ${ }^{91}$ Osim župnika i župnih djelatnika, ožalošćenima potporu mogu pružati osposobljeni svećenici i vjernici laici u radu sa tugujućima ili osobe koje su i same doživjele gubitak. ${ }^{92}$ Porast broja samaca starije dobi uzrokuje zabrinutost na mnogim razinama jer gotovo sve zemlje imaju udio stanovništva starijega od 60 godina iznad kritične razine, konkretno $7 \%$ od ukupnoga broja stanovnika.${ }^{93}$ Prema istraživanjima, stariji se samci više socijalno izoliraju, otuđuju i usamljuju, pa je osamljenost staraca jedna od pastoralnih i dušobrižničkih potreba, a tome je tako zbog sve slabije osjetljivosti prve i druge životne dobi za starije. Za pastoral samaca te dobi potrebna je prementalizacija koja u planovima i programima uključuje skrb za osamljenu starost. Pastoral samaca uključuje organiziranje prigodnih, redovitih susreta na osobnoj i župnoj razini, prožetih evangelizacijskim, katehetskim, društveno-kulturnim i zabavnim sadržajima koji će samcu olakšati samoću omogućujući mu dostojanstven život.

\section{Umjesto zaključka}

Iako je u Hrvatskoj sve veći udio osoba treće životne dobi u ukupnom broju stanovnika, pastoralna teorija i praksa nisu usklađene sa stanjem na terenu. Kao posljedicu toga pastoral treće životne dobi, napose kao subjekta pastoralnoga djelovanja, zahtijeva novo promišljanje o pastoralnim naglascima, pristupima i prioritetima. Budući da ne postoji strukturirana strategija pastoralnoga rada s trećom životnom dobi, stječe se dojam da ta životna dob ne dobiva potrebnu pozornost Crkve i društva. Zbog toga je u Crkvi u Hrvatskoj nužna prementalizacija pastoralnoga djelovanja, posebice u vidu konkretnijega planiranja i programiranja ponuda jer naše crkve u najvećem broju pohode upravo osobe treće životne dobi. Prvotna zadaća

${ }^{89}$ Usp. J. BOWLBY, Processes of mourning, u: International Journal of Psychoanalysis 42(1961.), 317 339.

${ }^{90}$ Usp. M. JAKŠIĆ, Gubitak, tugovanje i pružanje potpore, u: Služba Božja 54(2014.)3-4, 353-371., ovdje 357-358.

${ }^{91}$ Usp. Ti si Krist za nas i za sve ljude, br. 502.

92 Usp. M. JAKŠIĆ, Gubitak, tugovanje i pružanje potpore, 360.

${ }_{93}^{3}$ Usp. A. AKRAP, Samačka kućanstva u Hrvatskoj i odabranim europskim zemljama, u: J. BEBIĆ (ur.), Teološko promišljanje o pastoralu samaca, zbornik radova, Frankfurt am Main, 2010., 51-71., ovdje 60 . 
pastoralnih djelatnika jest osvijestiti društvo o vrijednostima koje nose starije osobe, među kojima se ističu mudrost i iskustvo, a koje je potrebno cijeniti i poštovati, ali i na pozitivan način iskoristiti na dobro svih. Kako bi osobe te dobi mogle biti prikladno vrjednovane, potrebno je odbaciti nametanje individualizma i sebičnosti i nadići mentalitet kojemu starije osobe smetaju zbog smanjene produktivnosti, bolesti i veće potrebe za skrbi. Neizostavno je istaknuti da starije osobe mogu biti djelatnici pastorala usmjerenoga prema svima, a osobito svojim vršnjacima, gdje mogu dati doprinos svojim sposobnostima, znanjima, iskustvom, mudrošću i duhovnom zrelošću. Tako mogu biti subjekt pastoralnoga djelovanja na mnogim razinama u skladu s vlastitim mogućnostima. Isto tako osobama treće životne dobi potrebna je i skrb u kojoj je važan angažman vjernika laika, posebno onih koji zanimanjem i stručnim usmjerenjem mogu dati doprinos pastoralnom djelovanju. $U$ tim pastoralnim aktivnostima nositelji trebaju biti zaređeni službenici i osobe posvećenoga života, a kako bi svi bili što kompetentniji u svom djelovanju, potrebno je omogućiti im prikladno i kvalitetno obrazovanje i osposobljavanje. Osim toga Crkva u nas mora imati hrabrosti uključiti teologe laike u pastoral starih, bolesnih, umirućih, žalujućih i osamljenih. Tek nastojanjem na svim razinama i svih djelatnika pastorala moguće je donijeti plod i spoznati zahtjevnost, ali i ljepotu pastorala toga usmjerenja koja se očituje u povezivanju osoba različitih dobnih skupina i životnih usmjerenja omogućujući pritom starima živjeti plodnu starost, a mladima ostvariti ljubav i brigu prema starima učeći od njih na svim razinama i dimenzijama njihova života. 


\title{
THIRD AGE AS THE SUBJECT OF PASTORAL ACTIVITY - POSSIBILITIES AND PERSPECTIVES
}

\author{
Stanislav ŠOTA*
}

Summary: Given that the population in Europe and Croatia is increasingly getting older, and the pastoral work of people in the third age is a relatively new term, the article firstly analyzes the question why people of this age group are partially put (left) aside by pastoralists and pastoral workers in pastoral discourse in Croatia. The nature and characteristics of the third age in life presented in the first part show that the third age pastoral care includes the pastoral work with the most mature middle-aged people struggling with many life difficulties and stresses: separation from their children, the need for making personal and lifestyle adjustments, especially after retirement, after children moving out or after the loss of a life partner, as well as experiencing fast and progressive weakening of biological, psychological and mental health dimensions, a drop in life energy, strength, and general decline in vital and all other functions. Old age as a gift and possibility is depicted through several biblical characters as an evangelizing and pastoral possibility, opportunity and call to a God filled and more meaning ful life. The second part presents the third age in the world and in the mentality of the society and the Church. By looking at the contemporary life context, we can state that words like old age, dying and death have become foreign in everyday discourse and that is just one of the many reasons why the third age people are often left to the side, and forsaken by their own families, society, friends and relatives, and partially forgotten also by the Church. In the world of the dictatorship of relativism, materialism, secularization, anarchism, atheism, subjectivism, individualism, and the selfie-culture, it is extremely difficult and demanding to accomplish the pastoral of the third age people. The Church, especially in Croatia, doesn't have a sufficiently designed, thought out, planned out and programmed systematic pastoral care which would include third age people. The new concept of pastoral discourse regarding the pastoral of the third age should develop in two basic directions: the first direction should consider to what extent can the third age be a subject of pastoral activity, and the second direction, based on pastoral sociology and demographic trends, should strive to recognize the third age as an object of pastoral activity. Besides the object, the third age can also be the subject of pastoral activity at different levels, areas and dimensions, especially at the parish level, the deanery level in some ways, at the regional level and (arch) diocesan level, in areas of apostolate, parish pastoral councils, charitable activities,

\footnotetext{
* Asst. Prof. Stanislav Šota, Ph. D., Catholic Faculty of Theology in Đakovo, J. J. Strossmayer University of Osijek, P. Preradovića 17, 31400 Đakovo, Croatia, stanislav.sota@os.t-com.hr
} 
Diacovensia 26(2018.)3

liturgy, families, religious associations and movements, and work with Christians that have distanced themselves.

Keywords: third age in life, old age as a challenge for pastoral theology, third age as a subject and object of pastoral activity. 